\title{
Distribution of ${ }^{15} \mathrm{~N}$ in Amino Acids During ${ }^{15} \mathrm{~N}$-Leucine Infusion: Impact on the Estimation of Endogenous Flows in Dairy Cows
}

\author{
H. Lapierre, ${ }^{\star 1}$ D. R. Ouellet, ${ }^{*}$ R. Berthiaume, ${ }^{\star}$ R. Martineau, ${ }^{*}$ G. Holtrop, $\dagger$ and G. E. Lobleył \\ *Agriculture and Agri-Food Canada, STN Lennoxville, Sherbrooke, Quebec, J1M 1 Z3 Canada \\ †Biomathematics and Statistics Scotland, Rowett Research Institute, Aberdeen, AB21 9SB United Kingdom \\ ‡Rowett Research Institute, Aberdeen, AB21 9SB United Kingdom
}

\section{ABSTRACT}

The distribution of ${ }^{15} \mathrm{~N}$ in AA during $\left[{ }^{15} \mathrm{~N}\right]$ Leu infusion and its impact on the estimation of endogenous nitrogen (EN) flows in dairy cows was evaluated in 4 lactating cows equipped with ruminal, duodenal ( $\mathrm{n}=$ $4)$, and ileal $(\mathrm{n}=2)$ cannulae fed a silage-based diet during a 35-d experimental period. To label EN, starting on $\mathrm{d} 27$, an infusion of L- $\left[{ }^{15} \mathrm{~N}\right] \mathrm{Leu}(0.45 \mathrm{mmol} / \mathrm{h})$ was performed for $200 \mathrm{~h}$. Samples of feed, duodenal and ileal digesta, feces, blood, urine, and mucosa of the rumen and duodenum were taken at 0900, 1100, 1300, and $1500 \mathrm{~h}$ on $\mathrm{d} 34$ and at $0800,1000,1200$, and 1400 $\mathrm{h}$ on $\mathrm{d} 35$. The enrichment and fluxes of total $\mathrm{N}$ and individual AA were determined and used to calculate the EN flows at the duodenum, ileum, and in the feces. Based on the concept that EN comprises desquamation and secretions, EN flows were estimated, using as representative of the enrichment of EN only the enrichment of the gut mucosa (upper limit) or the average of the mucosa and the export protein enrichment (assumed to have a similar enrichment to casein; lower limit). Estimations of duodenal and fecal EN flows using the isotope dilution of ${ }^{15} \mathrm{~N}$-total and ${ }^{15} \mathrm{~N}$-Leu were not different and EN was an important fraction of duodenal and fecal flows, representing 14 to $30 \%$ of the duodenal flow and 18 to $31 \%$ of the fecal flow, depending on the dilution method used. The total EN flow at the duodenum is present in approximately equal proportions as either free EN or EN incorporated into bacterial protein. Ileal EN flow was 18\% greater than the fecal EN flow. Using the combination of the gut and export protein, the duodenal and fecal EN flows estimated with the isotopic dilution of Leu vs. other labeled AA were less different than when estimated using the enrichment of gut mucosa alone. The current approaches have highlighted that present prediction schemes probably underestimate EN flows at the duodenum and, in conse-

Received November 16, 2007.

Accepted February 25, 2008.

${ }^{1}$ Corresponding author: lapierreh@agr.gc.ca quence, overestimate net protein and AA supply. Refinement of the procedures may allow direct and accurate estimation of metabolic fecal protein, an important component of the so-called maintenance requirement of dairy cows.

Key words: endogenous secretion, amino acid, dairy cow, leucine

\section{INTRODUCTION}

Flows of $\mathrm{N}$ into the gastrointestinal tract (GIT) originate from both exogenous (feed) and endogenous sources. The latter represents $\mathrm{N}$ previously digested that reenters the GIT in various forms, mainly proteins and urea, and from different routes, depending on the type of endogenous $\mathrm{N}(\mathbf{E N})$. Urea enters via saliva and passage through the GIT wall, whereas endogenous proteins enter the GIT through salivary, gastric, pancreatic, bile, and intestinal secretions, mucus, and sloughed cells (Tamminga et al., 1995). Part of these EN secretions into the GIT are reabsorbed and, on an $\mathrm{N}$ basis, do not represent a metabolic loss to the animal. The fraction of EN not digested and excreted in the feces does, however, represent a net loss for the animal. For the fraction of EN that is not reabsorbed, the form of entry into the GIT has an impact on MP requirement. Loss of $\mathrm{N}$ that has entered the GIT as urea does not impose an AA requirement whereas, in contrast, if $\mathrm{N}$ has entered the GIT as protein, it represents an AA cost to the animal. This loss, therefore, needs to be accounted for in the summation of protein or AA requirement.

Endogenous secretions have received considerable attention in pigs, and numerous studies have been conducted to determine factors that affect EN flows at the ileum, the true ileal igestibility of feed ingredients and subsequent true availability of dietary AA (Jansman et al., 2002). Corresponding data are scarce in ruminants, although important because estimations of $\mathrm{EN}$ in ruminants have a dual purpose: in addition to their contribution to metabolic losses of protein, EN also contributes substantially to the duodenal flow. Currently, RUP flow 
is usually estimated by difference between duodenal and microbial $\mathrm{N}$ flows. Therefore, ignoring the fact that EN can contribute up to $20 \%$ of duodenal N flow, as "free" EN or incorporated into bacterial protein (Ouellet et al., 2002, 2005), results in an overestimation of AA available on a net basis from RUP and microbial protein synthesis. The main challenge in ruminants is to find an adequate method for the measurements of EN. The earliest methods used in pigs (e.g., N-free diet method, diets with highly digestible protein sources, regression, and enzymatically hydrolyzed casein/ultrafiltration techniques; Jansman et al., 2002) cannot be transferred directly to the ruminant, because rumen microbial protein synthesis even in the absence of $\mathrm{N}$ intake.

More recently, stable ${ }^{15} \mathrm{~N}$ isotope approaches have been used to estimate EN flows, based on either labeling the animal or the diet (Sève and Lahaye, 2003). A common approach is to infuse $\left[{ }^{15} \mathrm{~N}\right]$ Leu over several days to label EN. Leucine is used because of its involvement in transamination reactions and, on a practical basis, due to a relatively low cost. The EN flows are estimated from the dilution of the isotopic enrichment (IE) in the digesta at any GIT site, relative to the IE of EN. Although offering improvements compared with earlier approaches, the isotopic dilution method also has limitations (Sève and Lahaye, 2003). In particular, the choice of the pool to represent the IE of the EN is critical, and the heterogeneity and sampling of EN represent real challenges. For practical purposes, initial studies in pigs used the IE of total N of the TCA-soluble fraction of plasma as representative of the IE of EN (Sève and Lahaye, 2003). Such an approach is questionable in pigs (de Lange et al., 1990; Lien et al., 1997a) and would be even less satisfactory in ruminants because of the large presence of urea derived from unlabeled ammonia in the plasma TCA-soluble fraction. Alternative, and better, representation of the IE of EN would be from the various endogenous protein sources, including mucins (Lien et al., 1997a; Leterme et al., 1998), the mucosa of the GIT (Hess et al., 1998; Ouellet et al., 2002), pancreatic secretions (Souffrant et al., 1993) and even milk casein, an easily accessible "export" protein (Ouellet et al., 2002).

Although labeled Leu is infused, the dilution of the IE of total $\mathrm{N}$ is traditionally used to calculate the EN flows. The contribution of ${ }^{15} \mathrm{~N}-\mathrm{Leu}$ in total ${ }^{15} \mathrm{~N}$ depends on the extent of transamination with other AA and the relative AA composition of EN. In addition, in ruminants, the transfer of labeled $\mathrm{N}$ from Leu to other AA may also occur through microbial protein synthesis in the rumen, using labeled $\mathrm{N}$ from either preformed labeled AA from EN or urea, and this may expand the distribution of labeled $\mathrm{N}$ to $\mathrm{AA}$ other than Leu and therefore improve the suitability of the ${ }^{15} \mathrm{~N}$-Leu infusion method. In pigs, because EN quantified from ${ }^{15} \mathrm{~N}-\mathrm{Leu}$ dilution were lower than estimations from dilution of total ${ }^{15} \mathrm{~N}$ or the transamination product ${ }^{15} \mathrm{~N}$-Ile (de Lange et al., 1992; Lien et al., 1997a), it has been suggested that transamination products would be better than Leu to estimate EN by dilution method. These results, however, were obtained using plasma TCA-soluble fraction as representative of the IE of EN. For these reasons, the validity of EN flows estimated using isotope dilution of total-N or single AA during a ${ }^{15} \mathrm{~N}$ [Leu] infusion needs to be assessed in ruminants, with appropriate representation of the IE of EN.

We hypothesized that estimation of EN in duodenal and fecal $\mathrm{N}$ flows in dairy cows would not differ when predicted using the dilution of ${ }^{15} \mathrm{~N}$ in either total $\mathrm{N}$ or Leu during a $\left[{ }^{15} \mathrm{~N}\right]$ Leu infusion, provided an appropriate representation of the IE of the EN was chosen. Therefore, our objectives were 1) to determine, during infusion of $\left[{ }^{15} \mathrm{~N}\right] \mathrm{Leu}$, the distribution of ${ }^{15} \mathrm{~N}$ in $\mathrm{AA}$ from different pools that might be used as representative of the IE of EN and 2) to estimate and compare the EN flows in the duodenal and fecal flows using the isotopic dilution of total-N, Leu and other AA that become labeled during a $\left[{ }^{15} \mathrm{~N}\right] \mathrm{Leu}$ infusion.

\section{MATERIALS AND METHODS}

\section{Cows and Diet}

Four lactating cows $(620 \pm 31 \mathrm{~kg}$ of BW and $20.0 \pm$ $6.0 \mathrm{~kg} / \mathrm{d}$ of milk) equipped with ruminal $(10 \mathrm{~cm}$; Bar Diamond Inc., Parma, ID; $\mathrm{n}=4$ ), duodenal (closed T, closed t-type Teflon-coated stainless steel; $\mathrm{n}=4$ ), and ileal (simple t-type, silastic; $n=2$ ) cannulae were fed a silage-based diet. The diet corresponded to one treatment of a larger study, in which the silage was a firstcut timothy (Phleum pratense L. cv. Champ), harvested after $20 \mathrm{~h}$ of wilting (1 tedding) and ensiled with an inoculant containing Lactobacillus plantarum LPH-1 and Pediococcus cerevisiae PCH-3 (final application rate of $1.25 \times 10^{5} \mathrm{cfu} / \mathrm{g}$ of fresh forage; Martineau et al., 2007). Briefly, the forage represented $54 \%$ of the ration $\mathrm{DM}$ and the ingredients in the concentrate $(\%$ of DM basis) were: $76.1 \%$ ground shelled corn, $13.2 \%$ soybean meal, 4.72\% Megalac (Church \& Dwight Co. Inc., Princeton, NJ), $4.17 \%$ mineral and vitamin premixes (DM basis: $20.2 \% \mathrm{Na} ; 7.8 \% \mathrm{Cl} ; 6.0 \% \mathrm{Ca} ; 0.3 \% \mathrm{P} ; 4.6 \%$ $\mathrm{Mg} ; 0.24 \% \mathrm{~K} ; 1.6 \% \mathrm{~S} ; 58.4 \mathrm{mg} / \mathrm{kg} \mathrm{Co} ; 5,192 \mathrm{mg} / \mathrm{kg} \mathrm{Mn}$; $7,788 \mathrm{mg} / \mathrm{kg} \mathrm{Zn} ; 31.2 \mathrm{mg} / \mathrm{kg} \mathrm{Se} ; 280 \mathrm{mg} / \mathrm{kg} \mathrm{Fe} ; 700,940$ IU of vitamin $\mathrm{A} / \mathrm{kg} ; 155,760 \mathrm{IU}$ of vitamin $\mathrm{D} / \mathrm{kg} ; 2,336$ IU of vitamin $\mathrm{E} / \mathrm{kg}$ ), $1.31 \%$ molasses; $0.51 \%$ Lignosol (Tempec, Temiscaming, Quebec, Canada). Chromium sesquioxide $\left(\mathrm{Cr}_{2} \mathrm{O}_{3}\right)$ was used as an indigestible marker; it was mixed with ground shelled corn (7.5:80.0, wt/wt, 
as-is basis), and $21.5 \mathrm{~kg}$ of this premix was included per tonne of concentrate before pelleting.

The diet was fed as a TMR and distributed every other hour in 12 equal meals per day with automated feeders (Ankom, Fairport, NY). In addition to the TMR, $1 \mathrm{~kg}$ (as fed) of unchopped hay was fed to prevent ruminal disturbances. The chemical composition of the diet and ingredients are presented in Martineau et al. (2007). During the experiment, the ration was restricted at $95 \%$ of the ad libitum DMI measured the first week of period 1 to maintain steady-state conditions and minimize variation in DMI. Animals were housed in individual tie stalls equipped with rubber mats and had free access to water throughout the trial. Animals were cared for according to the guidelines of the Canadian Council on Animal Care (CCAC, 1993) and all procedures involving animals were previously approved by the Institutional Animal Care Committee of the Dairy and Swine Research and Development Centre.

\section{Infusions and Sampling}

Experimental periods lasted for $35 \mathrm{~d}$ and detailed procedures are presented in Martineau et al. (2007). Adaptation to the diet was from d 1 to 16 . From d 16 to 22 , a total collection of urine and feces was performed. Cows were catheterized in one jugular vein on $\mathrm{d} 18$ and infused, starting on d 19 with $\left[{ }^{15} \mathrm{~N}_{2}\right]$ urea $(0.5 \mathrm{mmol} /$ h; 98\% purity, Cambridge Isotope Laboratories Inc., Andover, MA) for $72 \mathrm{~h}$ to estimate urea kinetics. On d 18 (to determine natural abundance) and 22, urine, duodenal, and fecal samples were collected at 0900 and $1000 \mathrm{~h}$ and pooled by day. To label EN, starting on $\mathrm{d}$ 27 , an infusion of L- $\left[{ }^{15} \mathrm{~N}\right] \mathrm{Leu}(0.45 \mathrm{mmol} / \mathrm{h} ; 99 \%$ purity, Cambridge Isotope Laboratories Inc.) was performed for $200 \mathrm{~h}$. Duodenal and ileal digesta, feces, and urine were sampled at $0900,1100,1300$, and $1500 \mathrm{~h}$ on d 34 and at $0800,1000,1200$, and $1400 \mathrm{~h}$ on d 35 . Duodenal sub-samples were formolized ( $300 \mathrm{~mL}$ plus $75 \mathrm{~mL}$ of formol physiological saline solution). Biopsies of the rumen and duodenal mucosa were taken following the same schedule, with an endometrial biopsy forceps for the rumen mucosa (approximately $10 \mathrm{mg}$ ) and with an optical fiber endoscope for the duodenal mucosa (approximately $5 \mathrm{mg}$ ) as described in Ouellet et al. (2002). Samples were rinsed with saline $(0.9 \% \mathrm{NaCl})$ immediately after collection and frozen until further analysis. Blood samples were collected by venipuncture from a coccygeal vessel according to the same schedule, into heparinized tubes, and immediately put on ice; plasma was harvested after centrifugation (15 min, 1,800 $\times g$ at $4^{\circ} \mathrm{C}$ ). All samples were stored at $-20^{\circ} \mathrm{C}$ for analyses. Feed samples were taken on both days and pooled. Milk samples were collected on d 34 at the evening milking and $\mathrm{d} 35$ at the morning milking. Casein was isolated from the milk by precipitation with acetic acid at $\mathrm{pH}$ 4.6. All biological tissues were sampled the morning before the initiation of the ${ }^{15} \mathrm{~N}$-Leu infusion to determine natural abundance.

\section{Analyses}

Samples collected during the urea infusion were pooled by day (d 18 and 22) and analyzed for the IE of urea (total $\mathrm{N}$ ) and duodenal bacteria and milk casein (total $\mathrm{N}$ and individual AA), as described below for samples taken during the $\left[{ }^{15} \mathrm{~N}\right]$ Leu infusion.

Samples collected at the end of the $\left[{ }^{15} \mathrm{~N}\right] \mathrm{Leu}$ infusion were analyzed individually for DM and N content. Dry matter in digesta and fecal samples was determined by lyophilization. All dried samples were ground through a 1-mm screen Wiley mill (Arthur H. Thomas, Philadelphia, PA) and analyzed for lab DM $\left(135^{\circ} \mathrm{C}\right.$ forced-air oven for $2 \mathrm{~h}$ for feed samples or $70^{\circ} \mathrm{C}$ vacuum-oven for $12 \mathrm{~h}$ for fecal samples). Chromium in digesta and fecal samples during the $\mathrm{N}$ balance period and in digesta collected on d 34 and 35 was measured by atomic absorption with an air-acetylene flame (Siddons et al., 1985). Amino acids in feed, digesta, and fecal samples were determined by an amino acid analyzer (Biochrom 20, Amersham Pharmacia Biotech, Piscataway, NJ) after 24-h acid hydrolysis with $6 \mathrm{~N}$ phenol-HCl at $110^{\circ} \mathrm{C}$.

A bacterial pellet was harvested from duodenal formolized digesta samples and used as reference for the ratio of purine to $\mathrm{N}$ in bacteria. Purine bases in bacteria and duodenal digesta were determined according to Zinn and Owens (1986) using $2 \mathrm{M} \mathrm{HClO}_{4}$ (Makkar and Becker, 1999) and the modified washing solution as proposed by Aharoni and Tagari (1991). An equimolar mixture of guanine and adenine was used as standard for the analysis of purine bases (Obispo and Dehority, 1999). Nitrogen concentration was determined after total combustion with a Leco Nitrogen Determinator (model FP-428, Leco Corp., St. Joseph, MI), whereas AA concentration in the bacteria were determined after acid hydrolysis with $6 \mathrm{~N}$ phenol-HCl for $24 \mathrm{~h}$ at $110^{\circ} \mathrm{C}$ (AOAC, 2000), and AA concentrations of the hydrolysates were determined by the isotope dilution method (Calder et al., 1999) using GC-MS (model CG6890MS5973, Hewlett Packard, Agilent Technologies, Wilmington, DE).

Samples were analyzed individually for the IE of total $\mathrm{N}$ in the ruminal and duodenal biopsies and in milk casein. Paired digesta and urine samples were pooled twice daily ( 0900 and $1100 \mathrm{~h}, 1300$ and $1500 \mathrm{~h}$ on d 34 and 0800 and $1000 \mathrm{~h}, 1200$ and $1400 \mathrm{~h}$ on $\mathrm{d}$ 35) for the 
determination of the IE of total N. All samples were pooled by day (d 25,34, and 35) for the IE of individual AA. The IE of ${ }^{15} \mathrm{~N}$-total were performed by total combustion using an elemental analyzer (Carlo Erba Strumentazione NA 1500, Milan, Italy) coupled to an isotope ratio mass spectrometer (C-IRMS: SIRA 12, VG Isogas, Middlewich, UK). The IE of ${ }^{15} \mathrm{~N}$-AA were measured, after protein hydrolysis, using GC-C-IRMS (Delta + XL fitted with a GC C II-III interface; Thermo Scientific, Winsford, UK). Approximately $10 \mathrm{mg}$ of protein was hydrolyzed in $7 \mathrm{~mL}$ of $6 \mathrm{M} \mathrm{HCl}$ in sealed tubes at $110^{\circ} \mathrm{C}$ for $18 \mathrm{~h}$ with added phenol crystals (to protect aromatic AA) and dithiothreitol (to protect methionine from oxidation). After drying under reduced pressure, the samples were dissolved in $0.1 \mathrm{M} \mathrm{HCl}$ and a portion converted to the $\mathrm{N}$-(tert-butyldimethylsilyl)-N-methyltrifluoroacetamide derivatives (Calder and Smith, 1988) before GC-C-IRMS analyses. The presence of a strongly colored hydrolysate (e.g., ileal and fecal samples) was found to interfere with the derivatization process and, when necessary, these hydrolysates were first partially decolored by passage through $0.6 \mathrm{~mL}$ of AG50 resin (x8, 100-200 mesh, Bio-Rad Laboratories Ltd., Mississauga, Ontario, Canada), washed with $3 \times 2 \mathrm{~mL}$ of water, and then eluted with $2 \mathrm{~mL}$ of $2 M \mathrm{NH}_{4} \mathrm{OH}$, followed by $1 \mathrm{~mL}$ of water; this was freeze-dried before dissolution in $0.1 \mathrm{M} \mathrm{HCl}$ and derivatization.

\section{Calculations and Statistical Analyses}

Duodenal, ileal, and fecal flows were calculated as described in Martineau et al. (2007). The EN flows were estimated as described previously (Ouellet et al., 2002). Continuous infusion of $\left[{ }^{15} \mathrm{~N}\right]$ Leu for several days results in labeling of proteins throughout the body and as a consequence, EN secretions into the GIT are enriched in ${ }^{15} \mathrm{~N}$. Briefly, the model developed for ruminants allows estimations of EN at the different sites of samplings with the separation at the duodenum of EN already incorporated into bacteria as opposed to "free" EN. It also allows separation of the contribution of urea-N recycled into the rumen and EN to duodenal protein flows. This model, however, considers that incorporation of ${ }^{15} \mathrm{~N}$ in the intestine is solely attributable to EN and does not account for the potential contribution of microbial synthesis using labeled urea. This is also ignored in pig models (e.g., Sève and Lahaye, 2003), as knowledge about microbial synthesis within the small intestine is limited and currently precludes any sensible inclusion of such microbial synthesis within the model.

The IE of the rumen and duodenal mucosa were used as representative of the IE of EN for pre-duodenal and intestinal EN proteins, respectively. In addition, based on estimations of EN passing into the GIT (Egan et al., 1984) indicating that approximately half of the protein EN were secretions and the other half was from epithelial abrasion, EN flows were estimated using the average enrichment of the corresponding gut mucosa and milk casein, the latter taken as representative of protein exported outside the tissue in which they are synthesized, as the gut secretions. Because the IE of Gly in the intestinal mucosa and of Phe in all the pools measured were not different from zero $(P>0.10)$, estimations of EN with the isotopic dilution of these $2 \mathrm{AA}$ were not included. To allow comparison between the different isotope dilution calculations, AA flows were converted to flows of CP, using the composition of abomasal isolate $(36,42,69,94,35,49$, and $46 \mathrm{~g}$ of AA/kg of CP for Leu, Ala, Asx, Glx, Ile, Ser, and Val respectively; Ørskov et al., 1986) and of endogenous CP at the terminal ileum of pigs (42.0, 42.6, 66.2, 80.6, 27.3, 48.2, and $38.6 \mathrm{~g}$ of AA/kg of CP for Leu, Ala, Asx, Glx, Ile, Ser, and Val, respectively; Jansman et al., 2002). Allowance was also made for the synthesis of microbial-N from urea- $\mathrm{N}$ based on the values for total IE and that of individual AA during the ${ }^{15} \mathrm{~N}$-urea infusion.

Flows were analyzed with the MIXED procedure of SAS (SAS Institute, 2001), with cow and the dilution method (total $\mathrm{N}$ or individual AA) as main effects, according to the model

$$
\mathrm{Y}_{i j}=\mu+\mathrm{a}_{i}+\mathrm{M}_{j}+\mathrm{e}_{i j}
$$

where $Y_{i j}$ is the response variable, $\mu$ is the overall mean, $\mathrm{a}_{i}$ is the effect of cow $i(1, \ldots, 4), \mathrm{M}_{j}$ is the effect of dilution method $j(1,2,3, \ldots)$, and $\mathrm{e}_{i j}$ is the residual error.

In addition, the IE were analyzed initially testing the interaction between dilution method and pools used to estimate the IE of $\mathrm{EN}$; because the interaction was always significant $(P<0.001)$, IE were then analyzed as follows. Within any particular pool that could be used to represent the IE of EN, cow and dilution method (total $\mathrm{N}$ or individual AA) were tested as the main effects (see previous model). Also, within an individual dilution method, cow and pool used to represent the IE of EN were tested as the main effects. The TukeyKramer test was used to separate the means, with $P<$ 0.05 regarded as significant.

\section{RESULTS AND DISCUSSION}

\section{Enrichment of AA in Pools Representative of the Enrichment of Endogenous Secretions}

The enrichment (as atom \% excess) of individual AA, as well as total $\mathrm{N}$ in pools that might represent the IE 
Table 1. Isotopic enrichment (atom percent excess, \%) of total $\mathrm{N}$ and individual AA in pools that may represent the enrichment of endogenous secretions across the gut in dairy cows infused with $\left[{ }^{15} \mathrm{~N}\right] l$ leucine ${ }^{1}$

\begin{tabular}{|c|c|c|c|c|c|c|c|c|c|c|c|}
\hline Pool & $\mathrm{Leu}^{2}$ & Total N & Ala & Asx & Glx & Gly & Ile & Phe & Ser & Val & SEM \\
\hline Rum & $0.2950^{\mathrm{A}}$ & $0.0206^{\mathrm{A}, \mathrm{e}}$ & $0.0103^{\mathrm{A}, \mathrm{bc}}$ & $0.0137^{\mathrm{A}, \mathrm{bcd}}$ & $0.0173^{\mathrm{A}, \text { cde }}$ & $0.0028^{\mathrm{A}, \mathrm{a}}$ & $0.0350^{\mathrm{A}, \mathrm{f}}$ & $0.0009^{\mathrm{A}, \mathrm{a}}$ & $0.0089^{\mathrm{A}, \mathrm{b}}$ & $0.0194^{\mathrm{A}, \mathrm{de}}$ & 0.0018 \\
\hline Duodenal mucosa & $0.2821^{\mathrm{A}}$ & $0.0267^{\mathrm{A}, \mathrm{c}}$ & $0.0200^{\mathrm{A}, \mathrm{abc}}$ & $0.0276^{\mathrm{B}, \mathrm{c}}$ & $0.0317^{\mathrm{B}, \mathrm{c}}$ & $0.0067^{\mathrm{A}, \mathrm{ab}}$ & $0.0677^{\mathrm{B}, \mathrm{d}}$ & $0.0014^{\mathrm{AB}, \mathrm{a}}$ & $0.0149^{\mathrm{B}, \mathrm{abc}}$ & $0.0252^{\mathrm{B}, \mathrm{bc}}$ & 0.0041 \\
\hline Milk casein & $0.5447^{\mathrm{B}}$ & $0.0599^{\mathrm{B}, \mathrm{e}}$ & $0.0496^{\mathrm{B}, \mathrm{cd}}$ & $0.0410^{\mathrm{C}, \mathrm{c}}$ & $0.0590^{\mathrm{C}, \mathrm{de}}$ & $0.0184^{\mathrm{B}, \mathrm{b}}$ & $0.0665^{\mathrm{B}, \mathrm{e}}$ & $0.0032^{\mathrm{B}, \mathrm{a}}$ & $0.0420^{\mathrm{D}, \mathrm{c}}$ & $0.0409^{\mathrm{C}, \mathrm{c}}$ & 0.0020 \\
\hline SEM & 0.0176 & 0.0018 & 0.0021 & 0.0009 & 0.0009 & 0.0017 & 0.0072 & 0.0005 & 0.13 & 0.0009 & - \\
\hline
\end{tabular}

${ }^{\mathrm{a}-\mathrm{f}}$ Means within a same row with different lowercase superscripts $\operatorname{differ}(P<0.05)$.

${ }^{\mathrm{A}-\mathrm{D}}$ Means within a same column with different uppercase superscripts differ $(P<0.05)$.

${ }^{1}$ All values are different from zero $(P<0.05)$, except Gly intestinal mucosa and all values for Phe, which are not different from zero $(P$ $>0.10$ ).

${ }^{2}$ Due to its very high enrichment, Leu was not included in the comparison within a pool between AA and total N.

${ }^{3}$ Free plasma includes only Glu.

${ }^{4} \mathrm{ND}=$ not determined.

of EN; that is, rumen and duodenal mucosa, milk casein, and plasma free AA are presented in Table 1. The IE of Lys, Pro, Thr, and Tyr were very low and not different from natural abundance and, therefore, are not presented. In addition to the relatively low cost, one of the reasons for the use of $\left[{ }^{15} \mathrm{~N}\right] \mathrm{Leu}$ infusion to determine $\mathrm{EN}$ is its role as a transamination substrate and this can be assessed from the extent of ${ }^{15} \mathrm{~N}$-label transferred to other AA. In the current study, the IE of Leu in all samples was much greater than for other AA. Based on the AA composition of gut proteins (MacRae et al., 1993), the ${ }^{15} \mathrm{~N}$ in Leu represented from 40 (duodenal mucosa) to $69 \%$ (rumen mucosa) of total ${ }^{15} \mathrm{~N}$, indicating that measurement of the IE of total $\mathrm{N}$ is dominated by the IE of Leu.

Variations of the Enrichment of AA Within a Pool. In all samples Leu had the greatest enrichment but the pattern of labeling of the other AA varied with sites. In the rumen mucosa, Ile presented the next greatest IE $(P<0.05)$, followed by $\mathrm{Val}$ and $\mathrm{Glx}$, then by Asx, Ala, Ser, and by Gly and Phe (Table 1). Similar differences $(P<0.05)$ were observed in the proteins of the mucosa of the duodenum, with the exception that Glx and Asx were more labeled than Val. The IE of milk casein followed the same trend, but with less differences between the branched-chain AA and the nonessential AA, with Ile not different from Glx but greater $(P<$ 0.05) than Ala, Asx, Ser, and Val, followed by Gly and Phe. In plasma free AA, Ile was the second greatest IE $(P<0.05)$, followed by Val and Ala and then by Ser, Glx, and Gly. The small concentrations of Asp precluded IE measurement in plasma. The IE of individual AA within a pool depends on several factors: these include the enrichments of the inflows of free AA into that pool from external sources (e.g., plasma or luminal digesta) and intracellular transamination coupled with the rates of protein breakdown and synthesis.
Variations of the Enrichment of AA Between Pools. The impact of differential inflows of free AA from plasma plus intracellular transamination at the various sites in the body is indicated by the difference in the ratio of the IE of the individual AA against that of Leu (Table 2). Ratio values for most AA were greater in duodenal than in ruminal mucosa and, indeed, for Glx, Ile, and Val even greater than in the plasma. Together, these data indicate that substantial transamination occurs for several AA within the duodenal mucosa. In contrast, for milk casein, Ala, Glx, and Ser had greater relative enrichments than in plasma, also suggestive of active transamination and this is in agreement with observations made across the mammary gland of dairy cows (Lapierre et al., 2005a).

The comparison of absolute values of IE, in addition to the ratios relative to Leu, also integrates the contribution of the fractional synthesis rate to the IE measured after $8 \mathrm{~d}$ of infusion. The IE were greater in the plasma than in the mucosa of the rumen and the duodenum for all AA, except Glx and Ile in the duodenal mucosa (Table 1). The former is expected because the AA used for protein synthesis at the cellular level are a combination of the AA supplied from plasma and lower-labeled AA derived from intracellular protein degradation. The fact that the IE in the duodenal mucosa was greater than in the plasma for Glx indicates Leu oxidation across the GIT (Lapierre et al., 2002) and a high level of transamination reactions in this section of the GIT, resulting in labeled Gln and (or) Glu. This has also been observed when comparing the IE of Glx in the TCA-soluble fraction and mucin in pigs (Lien et al., 1997b).

The IE of the duodenal mucosa was consistently greater than that of ruminal mucosa, the difference reaching significance $(P<0.05)$ for Asx, Glx, Ile, Ser, and Val, but with no difference for the IE of Leu. On 
Table 2. Isotopic enrichment (IE) of individual AA or total-N relative to IE of leucine (\%) in pools that could represent the enrichment of endogenous secretions across the gut in dairy cows infused with $\left[{ }^{15} \mathrm{~N}\right] l$ leucine

\begin{tabular}{lcccccccccc}
\hline Pool & Total N & Ala & Asx & Glx & Gly & Ile & Phe & Ser & Val & SEM \\
\hline Rumen mucosa & $7.0^{\mathrm{A}, \mathrm{e}}$ & $3.4^{\mathrm{A}, \mathrm{bc}}$ & $4.6^{\mathrm{A}, \mathrm{bcd}}$ & $5.8^{\mathrm{A}, \mathrm{cde}}$ & $0.9^{\mathrm{A}, \mathrm{a}}$ & $11.9^{\mathrm{A}, \mathrm{f}}$ & $0.3^{\mathrm{A}, \mathrm{a}}$ & $3.0^{\mathrm{A}, \mathrm{b}}$ & $6.5^{\mathrm{A}, \mathrm{de}}$ & 0.4 \\
Duodenal mucosa & $9.5^{\mathrm{B}, \mathrm{c}}$ & $7.0^{\mathrm{B}, \mathrm{bc}}$ & $9.9^{\mathrm{C}, \mathrm{c}}$ & $11.3^{\mathrm{C}, \mathrm{c}}$ & $2.3^{\mathrm{B}, \mathrm{ab}}$ & $24.1^{\mathrm{B}, \mathrm{d}}$ & $0.5^{\mathrm{A}, \mathrm{a}}$ & $5.2^{\mathrm{BC}, \mathrm{abc}}$ & $8.9^{\mathrm{C}, \mathrm{c}}$ & 1.3 \\
Milk casein & $11.0^{\mathrm{C}, \mathrm{d}}$ & $9.0^{\mathrm{C}, \mathrm{c}}$ & $7.5^{\mathrm{B}, \mathrm{c}}$ & $10.9^{\mathrm{C}, \mathrm{d}}$ & $3.3^{\mathrm{C}, \mathrm{b}}$ & $12.3^{\mathrm{A}, \mathrm{d}}$ & $0.6^{\mathrm{A}, \mathrm{a}}$ & $7.7^{\mathrm{D}, \mathrm{c}}$ & $7.5^{\mathrm{B}, \mathrm{c}}$ & 0.3 \\
Plasma & - & $7.0^{\mathrm{B}, \mathrm{b}}$ & - & $3.0^{\mathrm{B}, \mathrm{a}}$ & $2.5^{\mathrm{BC}, \mathrm{a}}$ & $12.1^{\mathrm{A}, \mathrm{c}}$ & - & $4.3^{\mathrm{B}, \mathrm{a}}$ & $7.1^{\mathrm{AB}, \mathrm{b}}$ & 0.4 \\
SEM & 0.1 & 0.4 & 0.3 & 0.4 & 0.2 & $2.1^{\mathrm{b}}$ & & $0.3^{\mathrm{b}}$ & $0.2^{\mathrm{b}}$ & - \\
Duodenal bacteria & $11.0^{\mathrm{b}}$ & $10.1^{\mathrm{b}}$ & $12.8^{\mathrm{bc}}$ & $12.9^{\mathrm{bc}}$ & $10.1^{\mathrm{b}}$ & $17.8^{\mathrm{d}}$ & $5.1^{\mathrm{a}}$ & $15.3^{\mathrm{cd}}$ & $13.9^{\mathrm{c}}$ & 0.6 \\
\hline
\end{tabular}

${ }^{\mathrm{a}-\mathrm{f}}$ Means within a same row with different lowercase superscripts differ $(P<0.05)$.

${ }^{\mathrm{A}-\mathrm{D}}$ Means within a same column with different uppercase superscripts $\operatorname{differ}(P<0.05)$; duodenal bacteria were not included in this analysis.

one hand, it might be expected that the precursor pool used for the synthesis of duodenal proteins would be diluted by dietary and microbial-derived AA compared with the arterial supply used at the rumen level but the biopsies were taken at the entrance of the duodenum and at this site, the availability of free AA from digested protein may be limited. On the other hand, the rate of protein synthesis is greater in the duodenum than in the rumen (Lobley et al., 1994), leading to more rapid incorporation of labeled AA, but after $8 \mathrm{~d}$ of infusion this will not necessarily lead to greater IE in the former, as both these high-turnover tissues should approach plateau enrichments (Early et al., 1990). The fact that the IE was not different for Leu between the rumen and duodenal mucosa would rather suggest an overall high transamination activity in the small intestine.

The IE of individual AA in milk casein was systematically greater $(P<0.05)$ than the IE of gut mucosa, except for Ile. They were similar to IE in plasma and were even higher $(P<0.05)$ for Glx and Ser, supportive of their mammary synthesis from labeled essential AA extracted in excess by the mammary gland (Lapierre et al., 2005a). The IE of milk protein has been shown to reach a level close to the IE of plasma after $30 \mathrm{~h}$ of infusion in dairy goats (Bequette et al., 1999). Milk casein can be compared with other proteins such as EN secretions that are exported from the tissue where they are synthesized. Indeed, pancreatic secretions also rapidly reached stable high IE during $\left[{ }^{15} \mathrm{~N}\right]$ Leu infusion in pigs (Souffrant et al., 1993) and this is in line with other export proteins in sheep (Connell et al., 1997).

Pattern of Labeling in Dairy Cows Compared with Nonruminants. These labeling patterns can be compared with observations in nonruminants, where tissue transamination will be the major route of transfer of ${ }^{15} \mathrm{~N}$ from Leu to other AA. It might be expected that the dairy cow would have a more even distribution of ${ }^{15} \mathrm{~N}$ between $\mathrm{AA}$, because a proportion of the microbial protein used as an anabolic source by the animal becomes labeled from ${ }^{15} \mathrm{~N}$-ammonia derived from rumen entry of urea. Such N-transfer into microbes gives a more uniform labeling pattern across the AA (Table 3). In practice, however, this route of label contribution is less than 20\% (from Table 4). Therefore, although the IE of duodenal bacteria during the $\left[{ }^{15} \mathrm{~N}\right]$ Leu infusion showed less variation between AA than in the endogenous proteins, Leu still dominated the total ${ }^{15} \mathrm{~N}$ in the bacteria (Table 3).

In pigs, patterns of IE in free AA of plasma showed that the branched-chain AA were the only essential AA labeled whereas enrichment was also detected in nonessential AA, such as Ala, Asp, Glu, Gly, Pro, and Ser (Gabert et al., 1997; Lien et al., 1997a; Leterme et al., 1998). Such patterns were also reflected in proteins (mucin, Lien et al., 1997b; gut mucosa, Hess et al., 1998). The enrichments of individual AA relative to Leu were, however, variable. For example, in the current study Ile was labeled at 12 to $24 \%$ of Leu enrichment (Table 2), comparable with 18 to $20 \%$ observed in free AA from canine (Matthews et al., 1979) and porcine (de Lange et al., 1992; Gabert et al., 1997) plasma, but lower than the relative enrichment ( 40 to $55 \%$ of Leu IE) observed in plasma free Ile and that from gut mucosal protein or mucins (Lien et al., 1997b; Hess et al., 1998). Overall, this would suggest that rates of tissue transamination (and exchange with plasma) may be lower in the dairy cow.

\section{Choice of Pool(s) that Could Best Represent the Enrichment of Endogenous Secretions}

A critical issue with the isotopic dilution technique concerns the choice of the best representation of the IE of the EN secretions during the infusion of $\left[{ }^{15} \mathrm{~N}\right] \mathrm{Leu}$. In dairy cows, an initial comparison has been made between 3 potential pools when using the IE of total N (Ouellet et al., 2002): 1) the duodenal mucosa, that would mainly represent the EN originating from sloughed cells; 2) milk casein, an easily accessible export protein that may mimic gastric or pancreatic enzyme secretions; 3) plasma TCA-soluble fraction, tradi- 




tionally used to estimate EN in pigs. The current study extends those comparisons to individual AA within these fractions.

Although in initial studies using isotopic dilution technique in pigs, it was assumed that the IE of the TCA-soluble fraction would be representative of the precursor pool for the synthesis of the EN secretions (Sève and Lahaye, 2003), this assumption has been challenged. Indeed, Lien et al. (1997a) have shown that only $51 \%$ of the $\mathrm{N}$ in this plasma fraction was as urea + ammonia + AA, which could therefore be linked to the IE of AA used for synthesis of EN. The situation is even less acceptable in ruminants: in nonruminants, urea is mainly derived from AA catabolism and therefore the IE of urea can approach the IE of total AA-N. Indeed, in pigs, the IE of urine during $\left[{ }^{15} \mathrm{~N}\right]$ Leu infusion is greater than the IE of total $\mathrm{N}$ in plasma TCA-soluble fraction in pigs (Souffrant et al., 1982; de Lange et al., 1990), probably reflecting the presence of N-components other than free AA in this plasma fraction, such as peptides and small proteins. In contrast, in dairy cows and other ruminants, a large proportion of ureagenesis originates from absorbed ammonia (Lapierre et al., 2005b): this will be mainly unlabeled and therefore should decrease the IE of urea. This is exactly as observed, with the IE of urine lower than the IE of the plasma TCA-soluble fraction during a $\left[{ }^{15} \mathrm{~N}\right]$ Leu infusion in dairy cows (Ouellet et al., 2002). Furthermore, in the current study, the concentration of plasma urea-N (8.5 $\mathrm{m} M$ ) was approximately 4-fold greater than that of total AA-N (2.2 mM; Martineau et al., 2007). For these reasons, the IE of total $\mathrm{N}$ in plasma TCA-soluble fraction is not a suitable representative pool for the estimation of the IE of EN in ruminants and has not been used for the calculations presented in this study.

Nonetheless, the different IE of AA within the pools used as representative of endogenous secretions illustrates the challenge to identify which are most appropriate to use during the isotopic dilution method. One simple option is to assume that the IE of the rumen mucosa would closely represent the IE of pre-duodenal EN and that the IE of the duodenal mucosa would match the IE of the intestinal EN. This site-specific distinction is necessary because of the different absolute enrichments of individual $\mathrm{AA}$ and their relative enrichments compared with ${ }^{15} \mathrm{~N}$-Leu (Table 2). A more complex but biologically valid option is to allow for nonmucosal inputs. Indeed, export proteins from specialized tissues such as the pancreas form part of the EN flows and may account for as much as $50 \%$ of EN flows (Egan et al., 1984). Gut export proteins are not easy to access, however, but the IE of another export protein such as milk casein can be used as a substitute. This would introduce EN inputs at greater IE than present 
Table 4. Isotopic enrichment (atom percent, \%) of total $\mathrm{N}$ and individual AA in compartments used to estimate endogenous flows across the gut in dairy cows infused with $\left[{ }^{15} \mathrm{~N}\right] l$ leucine

\begin{tabular}{|c|c|c|c|c|c|c|c|c|c|}
\hline Compartment & \multicolumn{9}{|c|}{ Amino acid or total $\mathrm{N}$} \\
\hline Feed & 0.36809 & 0.36714 & 0.36861 & 0.36951 & 0.36841 & 0.36830 & 0.36687 & 0.36912 & - \\
\hline Duodenal bacteria & $0.41456^{\mathrm{b}}$ & $0.37389^{\mathrm{a}}$ & $0.37634^{\mathrm{a}}$ & $0.37739^{\mathrm{a}}$ & $0.37669^{\mathrm{a}}$ & $0.37975^{\mathrm{a}}$ & $0.37732^{\mathrm{a}}$ & $0.37842^{\mathrm{a}}$ & 0.00181 \\
\hline Feces & $0.42563^{\mathrm{e}}$ & $0.37599^{\mathrm{a}}$ & $0.37939^{\mathrm{ab}}$ & $0.38051^{\mathrm{abc}}$ & $0.38142^{\mathrm{bc}}$ & $0.39095^{\mathrm{d}}$ & $0.37817^{\mathrm{ab}}$ & $0.38449^{c}$ & 0.00103 \\
\hline Rumen mucosa & $0.68145^{\mathrm{b}}$ & $0.39253^{\mathrm{a}}$ & $0.38498^{\mathrm{a}}$ & $0.38765^{\mathrm{a}}$ & $0.39093^{\mathrm{a}}$ & $0.41034^{\mathrm{a}}$ & $0.38257^{\mathrm{a}}$ & $0.393984^{\mathrm{a}}$ & 0.00791 \\
\hline
\end{tabular}

${ }^{\mathrm{a}-\mathrm{e}}$ Means within a same row with different lowercase superscripts differ $(P<0.05)$.

in gut mucosa and therefore decrease the estimates of EN flows. Clearly, there is a need to further refine our knowledge on the contribution of each of these fractions, but as a first approximation and for simplification, we have made a second set of estimations, assuming that half of the endogenous flow was from export proteins, whereas the other half was of mucosal origin (Egan et al., 1984). These latter calculations would yield a lower limit for EN estimations, whereas the sole utilization of gut mucosa would yield an upper limit.

\section{Endogenous Flows of $\mathbf{N}$ and AA Across the Gut}

A major challenge of working with dairy cows is size and relatively slow tissue protein turnover: these factors lead to high costs for isotope infusion. For this reason, we were constrained to use doses of $\left[{ }^{15} \mathrm{~N}\right] \mathrm{Leu}$ much smaller pro rata than those employed in pigs. This difficulty has been partly overcome by use of atom percent rather than atom percent excess in the calculation (Ouellet et al., 2002). Nevertheless, we have checked for carry-over between the urea and leucine infusions: background samples were taken before every infusion and the Leu enrichments (atom percent) measured for the 3 corresponding samples (casein, duodenal and fecal bacteria) analyzed by GC-C-IRMS on both d18 (pre-urea) and d25 (pre-Leu) were not different ( $P$ $>0.50$ ). Furthermore, greater sensitivity is achieved by analysis of the greater enrichment for ${ }^{15} \mathrm{~N}-\mathrm{Leu}$ compared with total ${ }^{15} \mathrm{~N}$ in both the pools and the sites of gut flow (intake, duodenum, and feces: Table 4). Flows of $\mathrm{N}$ and individual AA, measured directly (duodenal digesta, duodenal bacteria, feces) or estimated with the model developed for ruminants (duodenal bacteria from urea, EN, and feed; duodenal free EN; duodenal RUP; fecal EN, from undigested duodenal EN and from intestinal source; Ouellet et al., 2002) are presented in Table 5 . At the duodenum, EN flows are separated between free EN and EN incorporated into the bacterial protein, whereas in the feces, EN flows are divided between EN originating from undigested EN duodenal flow and EN from the intestine. The EN flow at the duodenum also

Table 5. Flows of $\mathrm{N}$ or individual AA ( $\mathrm{g} / \mathrm{d}$ ) across the gut, with the endogenous flows (EN) estimated using isotope dilution of ${ }^{15} \mathrm{~N}$ enrichment of total $\mathrm{N}$ or individual AA, and the mucosa of the gut as representative of the endogenous secretions ${ }^{1}$



${ }^{1}$ Mathematical means (SD). 
Table 6. Endogenous CP flows (EN, g/d) estimated using isotope dilution of ${ }^{15} \mathrm{~N}$ enrichment of total $\mathrm{N}$ or individual AA and AA composition of EN and the gut mucosa as representative of the endogenous secretions

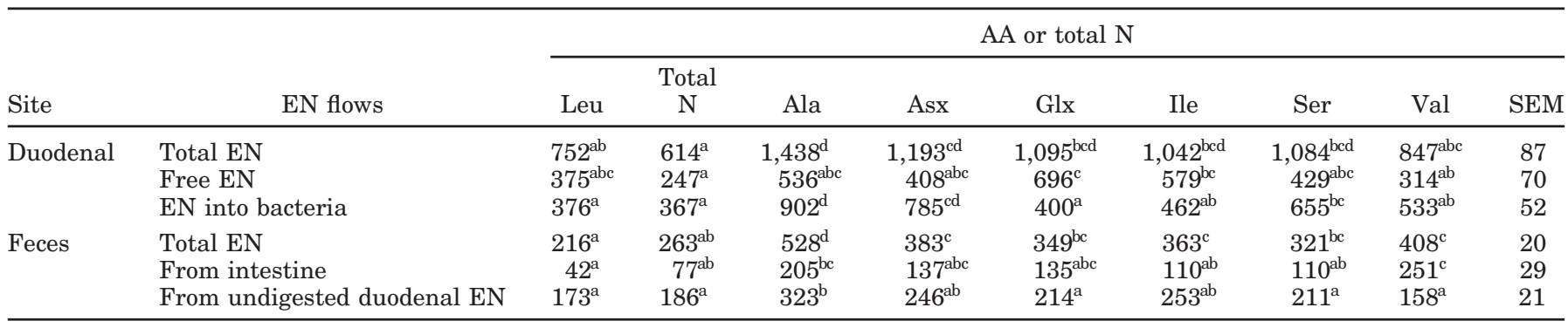

${ }^{\mathrm{a}-\mathrm{d}}$ Means within a same row with different lowercase superscripts differ $(P<0.05)$.

excludes the contribution from urea to bacteria flow because this was estimated separately based on the ratio of the IE of $\mathrm{N}$ or $\mathrm{AA}$ in the duodenal bacteria relative to the IE of urea measured during the $\left[{ }^{15} \mathrm{~N}_{2}\right]$ urea infusion (Table 3). Although this proportion differed $(P<0.05)$ across AA, the differences were small, mainly between 0.13 and 0.15 , except for Pro (average 0.11 ).

Flows of $\mathrm{N}$ and individual AA cannot be compared directly; instead they need to be converted into flows of CP, using the composition of AA in EN (see Materials and Methods). Currently, few reliable data exist for such composition in ruminants and this requires further investigation. Notably, current data report that the proportion of Leu declined from 9.0 to $4.8 \mathrm{~g}$ per 100 $\mathrm{g}$ of AA between ruminal vs. abomasal isolates of cattle given protein-free nutrients by intragastric infusion (Ørskov et al., 1986). Furthermore, no data are available in the ruminant for the AA composition of $\mathrm{EN}$ losses across the small intestine and, therefore, values from pigs on protein-free diets have been used (Jansman et al., 2002). With these provisos, the EN flows in the current cows are presented based on estimations of $\mathrm{EN}$ from isotopic dilution of total $\mathrm{N}$ or individual AA, using the IE of gut mucosa (Table 6) as maximal estimates, or the average of the IE of gut mucosa and milk casein (Table 7), as minimal values.
Estimations of Endogenous Flows using Dilution of Total N vs. Leu. Overall, although estimations of EN using a combination of gut mucosa and export proteins as representative of EN gave lower values than those based on gut mucosa alone, as the IE of milk casein is greater than gut mucosa, similar trends were observed with the two approaches. First, within each method, values estimated with the dilution of total ${ }^{15} \mathrm{~N}$ and ${ }^{15} \mathrm{~N}$-Leu were not significantly different (Tables 6 and 7). This contrasts with observation in pigs using the plasma TCA-soluble fraction (de Lange et al., 1992; Lien et al., 1997b), where EN flows based on total ${ }^{15} \mathrm{~N}$ were similar to those obtained from ${ }^{15} \mathrm{~N}$-Ile but much greater than those from ${ }^{15} \mathrm{~N}$-Leu. The better agreement between results obtained with the dilution of total $\mathrm{N}$ and Ile, compared with Leu was explained on the basis that both transamination (to form labeled Ile) and protein synthesis were intracellular processes using a similar cytosolic precursor pool. Utilization of the dilution of Leu might indeed underestimate EN when using a primary pool such as the TCA-soluble fraction, into which the tracer is directly infused, but with more appropriate representation of EN such a discrepancy was not present between total-N and Leu. The similarity between calculations based on total $\mathrm{N}$ and Leu in the current cows is expected because the latter contributed

Table 7. Endogenous CP flows (EN, g/d) estimated using isotope dilution of ${ }^{15} \mathrm{~N}$ enrichment of total $\mathrm{N}$ or individual AA and AA composition of EN, and the average enrichment of the gut mucosa and milk casein as representative of the endogenous secretions

\begin{tabular}{|c|c|c|c|c|c|c|c|c|c|c|}
\hline \multirow[b]{2}{*}{ Site } & \multirow[b]{2}{*}{ EN flows } & \multicolumn{9}{|c|}{ AA or total $\mathrm{N}$} \\
\hline & & Leu & Total-N & Ala & Asx & Glx & Ile & Ser & Val & SEM \\
\hline Duodenal & $\begin{array}{l}\text { Total EN } \\
\text { Free EN } \\
\text { EN into bacteria }\end{array}$ & $\begin{array}{l}546^{\mathrm{abc}} \\
273^{\mathrm{ab}} \\
273^{\mathrm{ab}}\end{array}$ & $\begin{array}{l}350^{\mathrm{a}} \\
141^{\mathrm{a}} \\
209^{\mathrm{a}}\end{array}$ & $\begin{array}{l}648^{\mathrm{bc}} \\
240^{\mathrm{ab}} \\
408^{\mathrm{de}}\end{array}$ & $\begin{array}{l}661^{\mathrm{bc}} \\
225^{\mathrm{ab}} \\
437^{\mathrm{e}}\end{array}$ & $\begin{array}{l}546^{\text {abc }} \\
346^{\text {ab }} \\
200^{\mathrm{a}}\end{array}$ & $\begin{array}{l}770^{\mathrm{c}} \\
433^{\mathrm{b}} \\
337^{\mathrm{bcd}}\end{array}$ & $\begin{array}{l}521^{\mathrm{ab}} \\
205^{\mathrm{ab}} \\
316^{\mathrm{bc}}\end{array}$ & $\begin{array}{l}589^{\text {abc }} \\
217^{\text {ab }} \\
371^{\text {cde }}\end{array}$ & $\begin{array}{l}51 \\
53 \\
18\end{array}$ \\
\hline Feces & $\begin{array}{l}\text { Total EN } \\
\text { From intestine } \\
\text { From undigested duodenal EN }\end{array}$ & $\begin{array}{c}155^{\mathrm{a}} \\
27^{\mathrm{a}} \\
128^{\mathrm{ab}}\end{array}$ & $\begin{array}{r}156^{\mathrm{a}} \\
46^{\mathrm{a}} \\
110^{\mathrm{a}}\end{array}$ & $\begin{array}{l}279^{\mathrm{c}} \\
115^{\mathrm{ab}} \\
165^{\mathrm{ab}}\end{array}$ & $\begin{array}{l}254^{\mathrm{bc}} \\
111^{\mathrm{ab}} \\
143^{\mathrm{ab}}\end{array}$ & $\begin{array}{c}207^{\mathrm{ab}} \\
93^{\mathrm{ab}} \\
114^{\mathrm{a}}\end{array}$ & $\begin{array}{l}294^{\mathrm{c}} \\
107^{\mathrm{ab}} \\
187^{\mathrm{b}}\end{array}$ & $\begin{array}{r}169^{\mathrm{a}} \\
54^{\mathrm{a}} \\
116^{\mathrm{ab}}\end{array}$ & $\begin{array}{l}311^{\mathrm{c}} \\
189^{\mathrm{b}} \\
122^{\mathrm{ab}}\end{array}$ & $\begin{array}{l}13 \\
23 \\
15\end{array}$ \\
\hline
\end{tabular}

${ }^{\mathrm{a}-\mathrm{e}}$ Means within a same row with different lowercase superscripts $\operatorname{differ}(P<0.05)$. 
considerably to the IE of the former and probably there was not a major distortion in the Leu composition of EN.

Estimations of Endogenous Flows Using Dilution of Leu vs. Other AA. In addition, total EN flows at the duodenum level did not differ when estimated using the dilution of the different AA with the combination of mucosa and export proteins, and estimations with Leu were only lower $(P<0.05)$ than estimations with Ala and Asx when mucosa was used alone. In contrast, in the feces, estimations of EN flows differed more across AA than at the duodenum level. Fecal EN flows estimated with dilution of Leu was lower $(P<$ 0.05 ) than when estimated with the dilution of all other AA when mucosa was used alone and was lower $(P<$ 0.05 ) than with Ala, Asx, Ile, and Val with the combination of mucosa and export proteins. This may be due partly to differences in the proportions of these AA in the EN secretions and partly because the processes that contribute to the enrichments (e.g., inflow into the precursor pool from plasma and protein breakdown) combined with the rate of intracellular transamination may differ between the various sites that contribute to EN in the various samples. Nonetheless, only calculations based on either total $\mathrm{N}$ or Leu enrichments will be considered in the further discussion.

Contribution of Endogenous Secretions to Gut Flows. Total CP flows $(\mathrm{N} \times 6.25)$ at the duodenum and in the feces averaged $( \pm \mathrm{SD}) 2,523 \pm 647$ and $840 \pm 198$ $\mathrm{g}$ of $\mathrm{CP} / \mathrm{d}$, respectively (Table 5). Contributions of total EN to $\mathrm{N}$ duodenal flow averaged 24 and $30 \%$ for total $\mathrm{N}$ and Leu, respectively, with mucosa as the representative pool. In sheep, Van Bruchem et al. (1997) reported that EN averaged $25 \%$ of duodenal $\mathrm{N}$ flow using labeled food, whereas Sandek et al. (2001) reported that EN contributed 3.4 and $12 \%$ of the NAN duodenal flow, using a combination of labeling and transferring digesta between animals.

Estimations obtained in this study correspond to 2.4 and $3.6 \mathrm{~g}$ of $\mathrm{N}$ per $\mathrm{kg}$ of DMI, for total $\mathrm{N}$ and Leu dilution, respectively, for the free portion of EN at the duodenum. If a mixture of mucosal plus export protein IE is used, then these values decline to 1.4 and $2.6 \mathrm{~g}$ of $\mathrm{N}$ per $\mathrm{kg}$ of DMI. If both free EN and that incorporated into bacteria are taken into account, then they would amount to 6.0 and $7.3 \mathrm{~g}$ of N/kg of DMI, using the dilution of total $\mathrm{N}$ and Leu with only the gut mucosa as the representative pool and to 3.4 and $5.3 \mathrm{~g}$ of N/kg of DMI using a combination of gut mucosa and export protein. This compares with a value of $1.9 \mathrm{~g}$ of N/kg of DMI adopted in the Nutrient Requirements for Dairy Cattle (NRC, 2001). Assuming a fractional synthesis rate of $29 \%$ for the fore-stomach (Lobley et al., 1980, 1994) and a CP mass of $3.5 \mathrm{~kg}$ (Gibb et al., 1992; Reynolds et al., 2004), total protein synthesis of the fore- stomach would amount to approximately $1.0 \mathrm{~kg} / \mathrm{d}$. With the total $\mathrm{N}$ dilution, total EN duodenal flow is estimated to be 350 or $614 \mathrm{~g}$ of $\mathrm{CP} / \mathrm{d}$ using the combination of the gut mucosa plus export proteins or only the gut mucosa as representative of the IE of EN, respectively, and these would contribute 34 or $60 \%$ of the total protein synthesis. This proportion would probably decrease taking into account any export proteins (only partially included in the fractional synthesis rate but included in the EN flows), and the true values probably lie between the minimal and maximal estimates.

The proportion of fecal $\mathrm{N}$ originating from undigested EN present at the duodenum was the major contributor to total EN in the feces, based on the assumption that a similar digestibility can be applied to all $\mathrm{N}$ fractions across the intestine (Ouellet et al., 2002). Accurate determination of fecal EN flow should provide a close approximation of metabolic fecal protein losses (Lapierre et al., 2007) associated with AA losses. Based on work from Swanson (1977), NRC (2001) estimates metabolic fecal protein as $4.8 \mathrm{~g}$ of $\mathrm{N}$ per $\mathrm{kg}$ of DMI minus $0.5 \times$ bacteria duodenal flow not digested in the small intestine. In the current study, that would represent $337 \mathrm{~g}$ of metabolic fecal protein. Requirement for MP to account for metabolic fecal loss should be the AA portion of CP EN (0.80) divided by an efficiency of utilization of MP into product; 0.67 is the value used by NRC (2001). Values therefore obtained for MP requirement to support EN fecal flows in the current study are lower (232 to $393 \mathrm{~g}$ of MP/d) based on dilution of Leu or total $\mathrm{N}$, using combined pools or mucosa alone. In addition, this estimation includes any intestinal contribution from labeled urea to fecal ${ }^{15} \mathrm{~N}$ flow. Nonetheless, it must be recognized that to better assess true losses of $\mathrm{AA}$ and MP requires EN flows to be measured at the ileum and not the feces, because fermentation of EN may occur in the large intestine and reduce the fecal outflow of ileal EN. Unfortunately, only 2 cows in this study had patent ileal cannulae but these exhibited greater ileal than fecal EN flows (Table 8). For the total $\mathrm{N}$, ileal EN flow was $18 \%$ greater than in the feces. Higher values were obtained based on ${ }^{15} \mathrm{~N}$-Leu but the same qualitative pattern of greater ileal than fecal EN flows was observed. This correction would increase estimations of metabolic fecal losses at 273 to $463 \mathrm{~g}$ of MP/d, depending on the dilution method and the pool chosen.

\section{Future Directions and Technical Advances}

There are two problems associated with the ${ }^{15} \mathrm{~N}$-Leu method in dairy cows; one relates to costs and the other to the pattern of labeling in endogenous secretions. The first issue can be addressed by use of more sensitive methods for detecting enrichment changes. The values 
Table 8. Duodenal, ileal, and fecal endogenous CP flows (EN) estimated using isotope dilution of ${ }^{15} \mathrm{~N}$ enrichment of total $\mathrm{N}$ or individual $\mathrm{AA}$ and AA composition of EN, and the gut mucosa as representative of the endogenous secretions ${ }^{1}$

\begin{tabular}{llcr}
\hline Site & \multicolumn{1}{c}{ Flow } & Total N & Leu \\
\hline Duodenal & Total EN & 650 & 817 \\
& Free EN & 261 & 382 \\
& EN into bacteria & 389 & 435 \\
Ileal & Total EN & 305 & 460 \\
& From intestine & 114 & 297 \\
& From undigested duodenal EN & 191 & 163 \\
Feces & Total EN & 259 & 225 \\
& From intestine & 62 & 41 \\
& From undigested duodenal EN & 197 & 184 \\
\hline
\end{tabular}

${ }^{1}$ These values are presented as descriptive statistics (no statistical analyses) because they are the average of only 2 cows.

obtained for EN were similar for total ${ }^{15} \mathrm{~N}$ and ${ }^{15} \mathrm{~N}$ Leu, but the latter had approximately 15 -fold greater enrichment in the various pools. Therefore, even allowing for the slightly lower precision of the GC-CIRMS, compared with either dual inlet or continuous flow IRMS, the dose of $\left[{ }^{15} \mathrm{~N}\right]$ Leu infused could be 20 to $30 \%$ of the actual dose used and still obtain accurate and precise measures of ${ }^{15} \mathrm{~N}$-Leu. Against this must be set the additional time and costs of analyses of the IE of individual AA on the GC-C-IRMS and of AA composition in the gut flows. Furthermore, as already discussed, reliance on a single AA assumes that this forms a suitable proportion of the endogenous proteins and that we have an adequate knowledge of the proportion of this AA in EN.

The second issue would be to label AA-N in a more uniform manner and thus reduce the reliance on the presence of a single AA in precursors and products. A mixture of labeled AA has been suggested (de Lange et al., 1992; Lien et al., 1997b), but cost is currently prohibitive for the larger species. Another option is to label rumen ammonia and then use the ${ }^{15} \mathrm{~N}$-microbial protein as a precursor to label body tissue proteins. This is what happened indirectly during $\left[{ }^{15} \mathrm{~N}_{2}\right]$ urea infusion in the current study and where the enrichments of AA in duodenal bacteria averaged 0.96 to 1.18 that of Leu, compared with enrichments relative to Leu averaging 0.02 to 0.18 with the ${ }^{15} \mathrm{~N}-\mathrm{Leu}$ administration (Table 3). The notable exception during the $\left[{ }^{15} \mathrm{~N}_{2}\right]$ urea infusion was Pro with a lower IE, as previously reported from studies in vitro with rumen fluid (Atasoglu et al., 2004 ); this probably reflects preferential use of preformed Pro of either dietary or endogenous origin. One downside is that more isotope may need to be infused to ensure quantifiable enrichments in tissue proteins because of more loss of the label through urinary urea. Nonetheless, until these other options are tested, the ${ }^{15} \mathrm{~N}$-Leu approach is probably the most suitable, but further information is needed to strengthen some of the interpretations made.

Clearly, the complex inflows and outflows associated with EN determinations present several daunting challenges at both the technical and biological levels. The current study illustrates some of these concerns and provides some possible solutions, while other problems remain unresolved and require further investigation. Nonetheless, the information provided by these and other data in dairy cows (Ouellet et al., 2002, 2007) have raised important questions relating to current prediction schemes and provided the basis for a reanalysis of some the underlying concepts (Lapierre et al., 2007; Ouellet et al., 2007).

\section{CONCLUSIONS}

These results show that estimations of duodenal and fecal EN flows using the isotope dilution of the IE of ${ }^{15} \mathrm{~N}$-total and ${ }^{15} \mathrm{~N}$-Leu during a ${ }^{15} \mathrm{~N}$ [Leu] infusion were not different, regardless of whether the mucosa of the rumen and duodenum or a combination of gut mucosa and export proteins were used to estimate the IE of EN. Biologically, based on the concept that both desquamation and secretions compose EN, some combination of the 2 pools should be used. Regardless of the approach adopted, EN forms an important fraction of duodenal, ileal, and fecal flows. This and other recent studies with the isotope dilution technique have highlighted that present prediction schemes underestimate EN flows at the duodenum in dairy cows and consequently overestimate net protein and AA supply. Refinement of the procedures may allow direct and accurate estimation of metabolic fecal protein, an important component of the so-called maintenance cost of dairy cows.

\section{ACKNOWLEDGMENTS}

The authors thank the staff of the Lennoxville Dairy and Swine Research Centre for taking care of the animals; D. Bournival, M. Léonard, and S. Provencher for their dedicated technical support; A. Albert and E. Milne for the GC-C-IRMS measurements; and S. Méthot for statistical analyses. Part of this work was funded by the core grants to the Rowett Research Institute (Aberdeen, UK) and BioSS by the Scottish Executive. The authors also wish to acknowledge the financial support of "Les producteurs de lait du Québec," and Agriculture and Agri-Food Canada (Lennoxville research Contribution number 953).

\section{REFERENCES}

Aharoni, Y., and H. Tagari. 1991. Use of nitrogen-15 determinations of purine nitrogen fraction of digesta to define nitrogen metabolism traits in the rumen. J. Dairy Sci. 74:2540-2547. 
AOAC. 2000. Official Methods of Analysis. 17th ed. AOAC, Arlington, VA.

Atasoglu, C., A. Y. Guliye, and R. J. Wallace. 2004. Use of stable isotopes to measure de novo synthesis and turnover of amino acid-C and $-\mathrm{N}$ in mixed micro-organisms from the sheep rumen in vitro. Br. J. Nutr. 91:253-261.

Bequette, B. J., F. R. C. Backwell, C. E. Kyle, A. G. Calder, V. Buchan, L. A. Crompton, J. France, and J. C. MacRae. 1999. Vascular sources of phenylalanine, tyrosine, lysine, and methionine for casein synthesis in lactating goats. J. Dairy Sci. 82:362-377.

Calder, A. G., K. E. Garden, S. E. Anderson, and G. E. Lobley. 1999. Quantitation of blood and plasma amino acids using isotope dilution electron impact gas chromatography/mass spectrometry with $\mathrm{U}-{ }^{13} \mathrm{C}$ amino acids as internal standards. Rapid Commun. Mass Spectrom. 13:2080-2083.

Calder, A. G., and A. Smith. 1988. Stable isotope ratio analysis of leucine and ketoisocaproic acid in blood plasma by gas chromatography/mass spectrometry. Use of tertiary butyldimethylsilyl derivatives. Rapid Commun. Mass Spectrom. 2:14-16.

Canadian Council on Animal Care (CCAC). 1993. Guide to the Care and Use of Experimental Animals. Vol. 1. E. D. Olfert, B. M. Cross and A. A. McWilliam, ed. CCAC, Ottawa, Ontario, Canada.

Connell, A., A. G. Calder, S. E. Anderson, and G. E. Lobley. 1997. Hepatic protein synthesis in the sheep: Effect of intake as monitored by use of stable-isotope-labelled glycine, leucine and phenylalanine. Br. J. Nutr. 77:255-271.

de Lange, C. F. M., W. C. Sauer, W. B. Souffrant, and K. A. Lien. 1992. ${ }^{15} \mathrm{~N}$-leucine and ${ }^{15} \mathrm{~N}$-isoleucine isotope dilution techniques versus the ${ }^{15} \mathrm{~N}$-isotope dilution technique for determining the recovery of endogenous protein and amino acids in digesta collected from the distal ileum in pigs. J. Anim. Sci. 70:1848-1856.

de Lange, C. F. M., W. B. Souffrant, and W. C. Sauer. 1990. Real ileal protein and amino acid digestibilities in feedstuffs for growing pigs as determined with the ${ }^{15} \mathrm{~N}$-isotope dilution technique. J. Anim. Sci. 68:409-418.

Early, R. J., B. W. McBride, and R. O. Ball. 1990. Growth and metabolism in somatotropin-treated steers. III. Protein synthesis and tissue energy expenditure. J. Anim. Sci. 68:4153-4166.

Egan, A. R., K. Boda, and J. Varady. 1984. Regulation of nitrogen metabolism and recycling. Control of digestion and metabolism in ruminants. Pages 386-402 in Control of digestion and metabolism in ruminants. L. P. Milligan, W. L. Grovum, and A. Dobson. ed. A Reston Book, Prentice-Hall, Englewood Cliffs, NJ.

Gabert, V. M., N. Canibe, H. Jørgensen, B. O. Eggum, and W. C. Sauer. 1997. Use of ${ }^{15} \mathrm{~N}$-amino acid isotope dilution techniques to determine endogenous amino acids in ileal digesta in growing pigs. Acta Agric. Scand. A Anim. Sci. 47:168-177.

Gibb, M. J., W. E. M. Irvings, M. S. Dhanao, and J. D. Sutton. 1992. Changes in body components of autumn-calving Holstein Friesian cows over the first 29 weeks of lactation. Anim. Prod. 55:339-360.

Hess, V., J. N. Thibault, and B. Sève. 1998. The ${ }^{15} \mathrm{~N}$ amino acid dilution method allows the determination of the real digestibility and of the ileal endogenous losses of the respective amino acid in pigs. J. Nutr. 128:1969-1977.

Jansman, A. J. M., W. Smink, P. van Leeuwen, and M. Rademacher. 2002. Evaluation through literature data of the amount and amino acid composition of basal endogenous crude protein at the terminal ileum of pigs. Anim. Feed Sci. Technol. 98:49-60.

Lapierre, H., R. Berthiaume, G. Raggio, M. C. Thivierge, L. Doepel, D. Pacheco, P. Dubreuil, and G. E. Lobley. 2005b. The route of absorbed nitrogen into milk protein. Anim. Sci. 80:11-22.

Lapierre, H., J. P. Blouin, J. F. Bernier, C. K. Reynolds, P. Dubreuil, and G. E. Lobley. 2002. Effect of supply of metabolizable protein on whole body and splanchnic leucine metabolism in lactating dairy cows. J. Dairy Sci. 85:2631-2641.

Lapierre, H., L. Doepel, E. Milne, and G. E. Lobley. 2005a. Effect of lysine (Lys) supply on its utilization by the mammary gland. J. Anim. Sci. 83. J. Dairy Sci. 88(Suppl. 1):89. (Abstr.)

Lapierre, H., G. E. Lobley, D. R. Ouellet, L. Doepel, and D. Pacheco. 2007. Amino acid requirements for lactating dairy cows: Reconciling predictive models and biology. Pages 39-59 in Proc. Cornell
Nutrition Conference for Feed Manufacturers. Dpt. Anim. Science, Cornell University, NY.

Leterme, P., B. Sève, and A. Théwis. 1998. The current ${ }^{15} \mathrm{~N}$-leucine infusion technique is not suitable for quantitative measurements of ileal endogenous amino acid flows in pigs. J. Nutr. 128:1961-1968.

Lien, K. A., W. C. Sauer, and M. E. R. Dugan. 1997a. Evaluation of the ${ }^{15} \mathrm{~N}$-isotope dilution technique for determining the recovery of endogenous protein in ileal digesta of pigs: Effect of the pattern of blood sampling, precursor pools and isotope dilution technique. J. Anim. Sci. 75:159-169.

Lien, K. A., W. C. Sauer, R. Mosenthin, W. B. Souffrant, and M. E. R. Dugan. 1997b. Evaluation of the ${ }^{15} \mathrm{~N}$-isotope dilution technique for determining the recovery of endogenous protein in ileal digestion of pigs: effect of dilution in the precursor pool for endogenous nitrogen secretion. J. Anim. Sci. 75:148-158.

Lobley, G. E., A. Connell, E. Milne, A. M. Newman, and T. A. Ewing. 1994. Protein synthesis in splanchnic tissues of sheep offered two levels of intake. Br. J. Nutr. 71:3-12.

Lobley, G. E., V. Milne, J. M. Lovie, P. J. Reeds, and K. Pennie. 1980. Whole body and tissue protein synthesis in cattle. Br. J. Nutr. 43:491-502.

MacRae, J. C., A. Walker, D. Brown, and G. E. Lobley. 1993. Accretion of total protein and individual amino acids by organs and tissues of growing lambs and the ability of nitrogen balance techniques to quantitate protein retention. Anim. Prod. 57:237-245.

Makkar, H. P., and K. Becker. 1999. Purine quantification in digesta from ruminants by spectrophotometric and HPLC methods. Br. J. Nutr. 81:107-112.

Martineau, R., H. Lapierre, D. R. Ouellet, D. Pellerin, and R. Berthiaume. 2007. Effects of the method of conservation of timothy on nitrogen metabolism in lactating dairy cows. J. Dairy Sci. 90:2870-2882.

Matthews, D. E., E. Ben-Galim, and D. M. Bier. 1979. Determination of stable isotopic enrichment in individual plasma amino acids by chemical ionization mass spectrometry. Anal. Chem. 51:80-84.

NRC. 2001. Nutrient Requirements of Dairy Cattle. 7th rev. ed. Nat. Acad. Press, Washington, DC.

Obispo, N. E., and B. A. Dehority. 1999. Feasibility of using total purines as a marker for ruminal bacteria. J. Anim. Sci. 77:3084-3095.

Ørskov, E. R., N. A. MacLeod, and D. J. Kyle. 1986. Flow of nitrogen from the rumen and abomasum in cattle and sheep given proteinfree nutrients by intragastric infusion. Br. J. Nutr. 56:241-248.

Ouellet, D. R., M. Demers, G. Zuur, G. E. Lobley, J. R. Seoane, J. V. Nolan, and H. Lapierre. 2002. Effect of dietary fiber on endogenous nitrogen flows in lactating dairy cows. J. Dairy Sci. 85:3013-3025.

Ouellet, D. R., R. Berthiaume, G. Holtrop, G. E. Lobley, R. Martineau, and H. Lapierre. 2005. Endogenous nitrogen (EN) flows: Effect of methods of conservation of timothy in lactating dairy cows. J. Dairy Sci. 88(Suppl. 1):317. (Abstr.)

Ouellet, D. R., D. Valkeners, G. Holtrop, G. E. Lobley, and H. Lapierre. 2007. Contribution of endogenous secretions and urea recycling to nitrogen metabolism. Pages 1-24 in Proc. Cornell Nutrition Conference for feed manufacturers. Dept. Anim. Sci., Cornell University, NY.

Reynolds, C. K., B. Dürst, B. Lupoli, D. J. Humphries, and D. E. Beever. 2004. Visceral tissue mass and rumen volume in dairy cows during the transition from late gestation to early lactation. J. Dairy Sci. 87:961-971.

Sandek, A., K. Krawielitzki, J. Kowalczyk, F. Kreienbring, U. Schönhusen, M. Gabel, T. Żebrowska, H. Hagemeister, and J. Voigt. 2001. Studies on N-metabolism in different gastrointestinal sections of sheep using the digesta exchange technique. 2. Passage of endogenous nitrogen. J. Anim. Feed Sci. 10:605-618.

SAS Institute. 2001. System for Windows Release 8.2 (TS2M0). SAS Inst. Inc., Cary, NC.

Sève, B., and L. Lahaye. 2003. Nitrogen and amino acid cost of digestions: Dietary factors affecting ileal endogenous losses and consequences on the net availability of dietary amino acids for maintenance and growth. Pages 263a-263y in Proc. Ninth Int. Symp. 
Digestive Physiol. in Pigs. R. O. Ball, ed. University of Alberta, Edmonton, Canada .

Siddons, R. C., J. Paradine, D. E. Beever, and P. R. Cornell. 1985. Ytterbium acetate as a particulate-phase digesta-flow marker. Br. J. Nutr. 54:509-519.

Souffrant, W. B., R. Köhler, and G. Gebhardt. 1982. Détermination de l'azote endogène dans les contenus digestifs par la technique isotopique $\left({ }^{15} \mathrm{~N}\right)$. Pages $175-187$ in Physiologie digestive chez le porc. Les Colloques de l'INRA, no. 12, INRA Publ.

Souffrant, W. B., A. Rérat, J. P. Laplace, B. Darcy-Vrillon, R. Köhler, T. Corring, and G. Gebhardt. 1993. Exogenous and endogenous contributions to nitrogen fluxes in the digestive tract of pigs fed a casein diet. III. Recycling of endogenous nitrogen. Reprod. Nutr. Dev. 33:373-382.
Swanson, E. W. 1977. Factors for computing requirements for protein for maintenance of cattle. J. Dairy Sci. 60:1583-1593.

Tamminga, S., H. Schulze, J. Van Bruchem, and J. Huisman. 1995. The nutritional significance of endogenous N-losses along the gastro-intestinal tract of farm animals. Arch. Anim. Nutr. 48:9-22.

Van Bruchem, J., J. Voigt, T. S. Lammers-Wienhoven, U. Schönhusen, J. J. Ketelaars, and S. Tamminga. 1997. Secretion and reabsorption of endogenous protein along the small intestine of sheep: Estimates derived from ${ }^{15} \mathrm{~N}$ dilution of plasma non-protein-N. Br. J. Nutr. 77:273-286.

Zinn, R. A., and F. N. Owens. 1986. A rapid procedure for purine measurement and its use for estimating net ruminal protein synthesis. Can. J. Anim. Sci. 66:157-166. 